\title{
A diffúz nagy B-sejtes lymphoma modern szemlélete és kezelése
}

\author{
Gergely Lajos dr. - Illés Árpád dr. \\ Debreceni Egyetem, Általános Orvostudományi Kar, Belgyógyászati Intézet, Hematológiai Tanszék, Debrecen
}

\begin{abstract}
A diffúz nagy B-sejtes lymphoma a leggyakoribb a non-Hodgkin-lymphomák között. A ciklofoszfamid-vincristinadriablastin-prednisolon kemoterápiával a betegeknek már közel 50\%-a meggyógyítható volt, majd a rituximab hozzáadásával a gyógyulási arány már $60 \%$ fölé emelkedett. Ez a javulás jelentős, de további növekedést kellene elérni a betegek gyógyulási arányában. Az utóbbi években elvégzett genetikai vizsgálatok számos új, a patogenezisben is szerepet játszó és terápiás célpontként is szolgáló mutációt azonosítottak a betegségben. A diagnosztika ma már rutinszerűen alkalmazza a 18-fluoro-deoxi-glükóz-pozitronemissziós komputertomográfiás vizsgálatokat a Lugano klasszifikációs rendszer részeként. Ezen adatok alapján egyre pontosabban meghatározható a betegek prognózisa, és kiválaszthatók azok a betegek, akik valamelyik új, szelektíven ható gyógyszerre esetleg reagálhatnak. Mindezeknek a kérdéseknek a megválaszolása, az újabb kezelések bevezetése várhatóan a közeli jövőben tovább fogja javítani a betegek túlélési esélyeit. Az összefoglaló közlemény áttekintést ad a közelmúlt újdonságairól, kiemeli a ma használatos és javasolt kezeléseket, továbbá áttekintést ad a jelenleg kipróbálás alatt álló és bevezetendő kezelésekről is. Orv. Hetil., 2016, 157(31), 1232-1241.
\end{abstract}

Kulcsszavak: lymphoma, DLBCL, kezelés

\section{Recent advances in the understanding and treatment of diffuse large B-cell lymphoma}

Diffuse large B-cell lymphoma is the most common type of non-Hodgkin's lymphoma. Using the conventional cyclophosphamide adriablastin vincristin prednisolon polychemotherapy about $50 \%$ of the patients were cured. The addition of rituximab to the regimen increased the cure rate to $60 \%$. This is a major improvement, however, further advance is still needed to increase the cure rate. The extensive genetic testing performed recently revealed several important pathognomic mutations as potential targets in this disease. Routine diagnosis of patients now includes the use of ${ }^{18}$ Fluor-deoxy-glucose positron emission computer tomography, according to the recent Lugano classification system. With all these data we can better predict the prognosis of patients, and we can select candidates for novel targeted therapies as well. Answering these questions, and utilizing novel therapies possibly will further increase the cure rate in the near future. This paper summarizes current diagnostic and therapeutic approaches and describes recent understanding in the mutations and pathognomic changes resulting in the disease. The authors also summarize the data available on experimental therapies possibly entering clinical pratice in the forthcoming years.

Keywords: lymphoma, DLBCL, treatment

Gergely, L., Illés, Á. [Recent advances in the understanding and treatment of diffuse large B-cell lymphoma]. Orv. Hetil., 2016, 157(31), 1232-1241.

(Beérkezett: 2016. március 16.; elfogadva: 2016. május 22.)

\begin{abstract}
Rövidítések
${ }^{18} \mathrm{FDG}=18$-fluoro-deoxi-glükóz; $\mathrm{ABC}=$ aktivált $\mathrm{B}$-sejtes; ADCC = antitest-közvetített sejt mediálta citotoxicitás; anti$\mathrm{HBc}=$ hepatitis B-vírus-mag-antigén elleni ellenanyag; ARIDlA = AT-ben gazdag interaktív domént tartalmazó pro-
\end{abstract}

tein 1 ; bcl-2 = B-sejtes lymphoma protein 2; bcl-6 = B-sejtes lymphoma protein $6 ; \mathrm{BCR}=\mathrm{B}$-sejt-receptor; $\mathrm{BEAM}=$ bicnu, etopozid, citozin-arabinozid, melphalan polikemoterápia; Btk = Bruton-féle tirozinkináz; CARDll = kaszpázasszociált doménprotein; $\mathrm{CD}=$ „cluster of differentiation” sejtfelszíni 
antigén jelölése; $\mathrm{CHOP}=$ ciklofoszfamid, adriablastin, vincristin, prednisolon polikemoterápia; CODOX-M/IVAC $=$ ciklofoszfamid, vincristin, adriablastin, metotrexát/ifoszfamid, etopozid, citozin-arabinozid polikemoterápia; CORAL = kollaborációs vizsgálat visszaeső agresszív lymphomában; CT = komputertomográfia; CTLA-4 = citotoxikus T-lymphocytához asszociált fehérje 4; DA-EPOCH = dózisadaptált etopozid, ciklofoszfamid, adriablastin, vincristin, prednisolon; DHAP = dexamethason, nagy dózisú citozin-arabinozid, cisplatin polikemoterápia; DLBCL = diffúz nagy B-sejtes lymphoma; $\mathrm{D}_{\max }=$ legnagyobb átmérő; $\mathrm{E}=$ epratuzumab; EBV = Epstein-Bar-vírus; ECOG PS = Keleti kollaborációs onkológiai csoportosulás aktivitási skála; EFS24 = 24 hónapos eseménymentes túlélés valószínűsége; ESHAP = etopozid, citozin-arabinozid, cisplatin polikemoterápia; $\mathrm{EZH} 2$ = hiszton-lizin- $\mathrm{N}$-metil-transzferáz enzim; FISH = fluoreszcens in situ hibridizáció; GCB = germinális centrum B-sejtes; GEP = génexpressziós profil; HAART = nagy hatékonyságú antiretrovirális terápia; $\mathrm{HBsAg}=$ hepatitis B-vírus felszíni antigén; $\mathrm{HCV}=$ hepatitis C-vírus; $\mathrm{HDACi}=$ hiszton-deacetiláz-inhibitor; HHV = humán herpeszvírus; HIV = humán immundeficientia-vírus; HLA = humán leukocyta-antigén; HyperCVAD/MA = hiperfrakcionált ciklofoszfamid, vincristin, adriablastin, dexamethason/metotrexát, citozin-arabinozid alternáló polikemoterápia; ICE = ifoszfamid, carboplatin, etopozid polikemoterápia; IF = érintett mező (besugárzásnál); IgH = immunglobulin-nehézlánc; IPI = nemzetközi prognosztikai index; IPI24 = módosított nemzetközi prognosztikai index; Ki-67 = sejtproliferációs marker protein; $\mathrm{KMR}=$ komplett metabolikus remisszió; KMT2A = hisztonlizin-N-metil-transzferáz $2 \mathrm{~A} ; \mathrm{LCA}=$ lymphocyta közös antigén; $\mathrm{LDH}$ = laktátdehidrogenáz; Lymph $2 \mathrm{CX}$ = digitális génexpressziós vizsgálati panel lymphomában; MALT = mucosaasszociált lymphoid szövet; MEF2B = monocytafokozó kötőfaktor 2; MRI = mágneses rezonanciás képalkotás; mTOR = rapamycin emlős targetje; $\mathrm{MUMl}=$ interferonreguláló protein 4; MYD88 = myeloid differenciációs primer válasz gén 88 ; $\mathrm{NF}=$ nukleáris faktor; $\mathrm{NGS}=$ új generációs szekvenálás; NOS = külön nem részletezett; OS = teljes túlélés; OX40 = tumornekrózis faktor szupercsalád fehérje 4 ; PAX $5=$ „paired box 5 ” fehérje - transzkripciós faktor; PCR = polimeráz láncreakció; $\mathrm{PDl}=$ programozott halál antigén $1 ; \mathrm{PD}-\mathrm{lL}=$ programozott halál ligand $1 ; \mathrm{PET} / \mathrm{CT}=$ pozitronemissziós tomográfia és komputertomográfia; PFS = progressziómentes túlélés; PI3K = foszfo-inozitol-3-kináz; PIMl = protoonkogén szerin/treonin kináz 1 ; PMBL = primer mediastinalis nagy $\mathrm{B}$-sejtes lymphoma; $\mathrm{PR}=$ parciális remisszió; $\mathrm{PRP}=$ mintázatfelismeró peptidek; PTLD = poszttranszplantációs lymphoproliferativ betegség; $\mathrm{R}=$ rituximab; REAL = átdolgozott európai és amerikai lymphomaklasszifikáció; RhoH/TTF = ras géncsaládba tartozó GTPáz enzim; R-IPI = módosított nemzetközi prognosztikai index; RNS = ribonukleinsav; SUV = szelektív izotópfelvételi érték; $\mathrm{SUV}_{\max }=$ legnagyobb szelektív izotópfelvételi érték; TP53 = sejtciklus-szabályozó fehérje; WHO = Egészségügyi Világszervezet; WIF1 = Wnt-gátló faktor 1

A non-Hodgkin-lymphomák REAL-osztályozása óta külön entitás egy nagy heterogén agresszív lymphomacsoport, amit diffúz nagy B-sejtes lymphomaként (DLBCL) ismerünk. Számos nagyon eltérő klinikummal rendelkező betegség tartozik ide. A 2008-ban elfogadott legújabb WHO-lymphomaklasszifikáció ezt jól tükrözi, hiszen számtalan speciális entitást sorol a csoportba. A közös jellemző, hogy a tumorsejtek érett nagy B-lymphocyták, jellemző morfológiával és felszíni markerexpresszióval (CD20+, CD79a+). Ugyanakkor a csoporton belüli heterogenitás számos sajátos megfontolást, eltérő diagnosztikát és kezelést igényelhet, amit az összefoglalóban igyekszünk ismertetni. A WHO-klasszifikáció pontosan azért kezeli egy gyújtőcsoportként, mert azt még könnyü definiálni. Az egyes alcsoportok azonosítása néha nehézségekbe ütközhet, különösen a mai igényeknek megfelelő molekuláris karakterizálás, így ez még nem is képezi a rutindiagnosztika és prognosztika részét. Ez a lymphomatípus a leggyakoribb, földrészenként eltérő frekvenciával fordul elő, de akár az összes lymphoma 34-42\%-a is lehet. Az összes agresszív lymphoma 75$80 \%$-a tartozik ebbe a nagy gyújtőcsoportba. A diagnózist követően a megfelelő stagingvizsgálatok elvégzése segíti a megfelelő kezelés kivitelezését, amivel a betegek 65\%-a él 5 év múlva. A ma használatos egyre hatásosabb immunokemoterápiák és hamarosan bevezetendő célzott terápiák egyre jobb kezelési eredményekhez vezetnek, várhatóan a túlélés tovább fog nőni még idősebb, komorbid betegekben is úgy, hogy egyre kedvezőbb toxicitási profillal rendelkező kezeléseket tudunk alkalmazni.

Ez az összefoglaló a betegséggel kapcsolatos ismeretek mellett a jelenlegi és a közeli jövőben elérhető kezelési lehetőségeiket is bemutatja.

\section{A DLBCL WHO-osztályozása}

A non-Hodgkin-lymphomák osztályozása egészen 1994-ig, a REAL (Revised European American Lymphoma Classification) -rendszer bevezetéséig nem volt egységes a világon. Az Európában a '70-es évektől használatos kieli felosztásban már megjelent a centrocytáscentroblastos és centroblastos lymphoma, amely az érett B-sejtes lymphomákat tartalmazta. Az 1994-ben bevezetett REAL-osztályozásban jelent meg először a diffúz nagy B-sejtes (DLBCL) lymphoma mint önálló entitás. A patológusok számára viszonylag könnyű volt a klasszifikáció, ugyanakkor a klinikusok azzal szembesültek, hogy a betegek klinikuma és prognosztikája rendkívül eltérő volt. Ez azt eredményezte, hogy a következő WHO-osztályozásban, amelynek jelenleg a 2008-as verzióját használjuk, a DLBCL-csoporton belül számos eltérő prognosztikájú és klinikumú entitás kapott helyet, mint variánsok és altípusok (1. táblázat). Ezek az eltérő csoportok már segítették a klinikust is a megfelelő kezelés, terápiás stratégia megválasztásában. Az utóbbi években egyre több információ áll rendelkezésre a betegség hátterében álló mutációkról a next generation sequencing (NGS-) technika széles körü alkalmazásával. Ez új terápiás célpontok azonosítását is lehetővé tette, és a 2008-as felosztást tovább finomította. A várhatóan 2016 őszén megjelenő új WHO-felosztás továbbra is meg- 


\section{1. táblázat |A DLBCL különböző felosztásai}

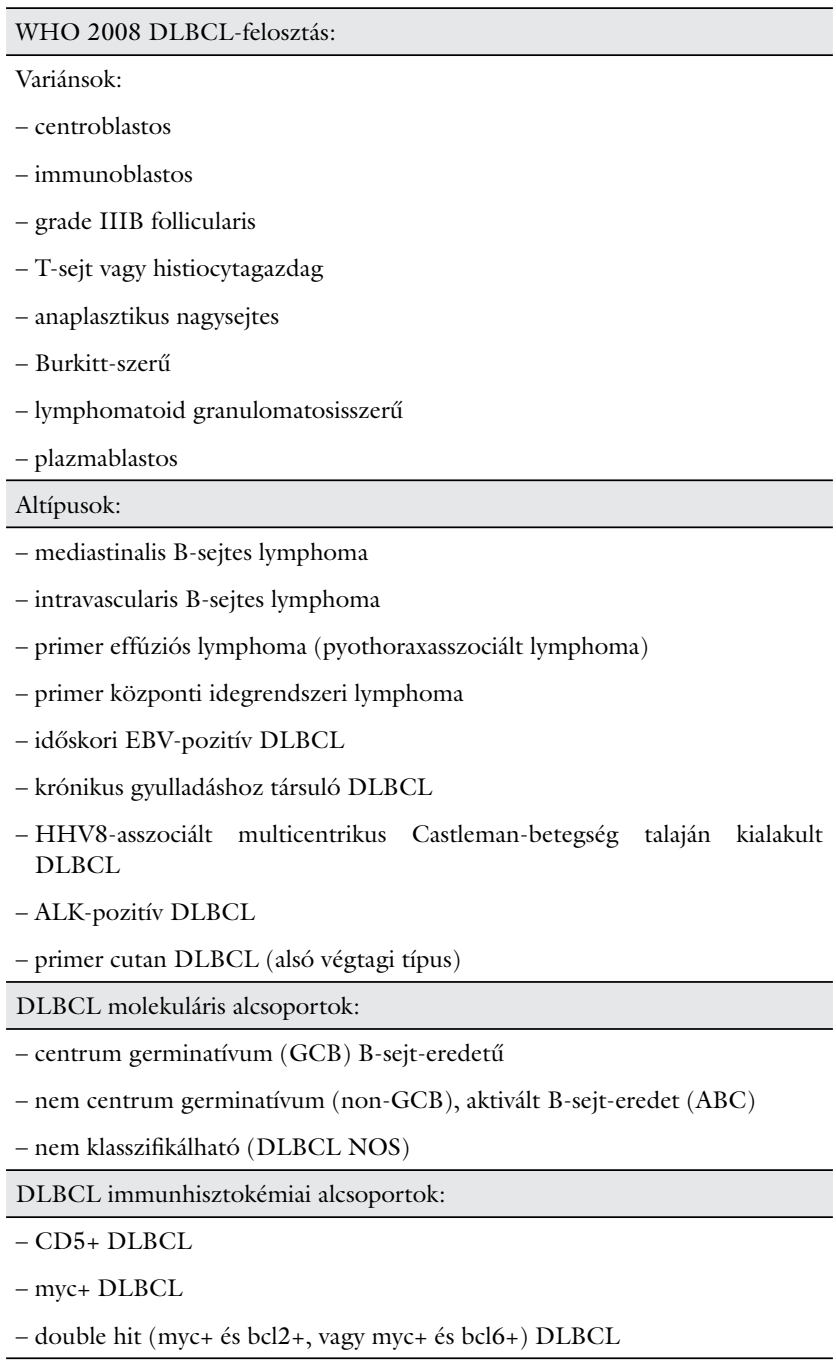

hagyja a DLBCL főcsoportot, de tovább finomítja a beletartozó entitásokat, elsősorban a genetikai információk alapján. Az osztályozás egyértelműen rögzíti, hogy a Hans-algoritmus alapján kötelező meghatározni a sejteredetet. Új morfológiai variáns lesz a blastos megjelenésű DLBCL. Az EBV-pozitív DLBCL nem csak az idős populációra lesz meghatározva. A diagnóziskor meg kell adni az osztódás mértékét (Ki-67), és minden nagy proliferációs aktivitású lymphomában javasolt a double és triple hit keresése, amelyek prognosztikai faktorok lesznek, tehát nem részei a klasszifikációnak.

\section{A DLBCL etiológiája}

A diffúz nagy B-sejtes lymphoma kialakulásának oka nem ismert, de ennek ellenére számos belső és külsô okot ismerünk, amely közrejátszhat a betegség kialakulásában. Ezek a nem specifikus okok nemcsak a DLBCLre, hanem a lymphomákra általában vonatkoznak. Egyes speciális altípusai a betegségnek, ugyanakkor egyértelmú asszociációt mutatnak vírusfertőzésekkel. Ilyen a humán herpeszvírus-8- (HHV8-) fertőzéssel asszociált primer effuzionális lymphoma. Az Epstein-Barr-vírus (EBV), ami egy viszonylag nagy DNS-tartalmú gamma-herpeszvírus (HHV4), igazoltan szerepet játszik több DLBCLcsoportba tartozó betegség patogenezisében is, ezek:

- pyothoraxasszociált B-sejtes lymphoma;

- poszttranszplantációs lymphoproliferativ betegség (PTLD), amely morfológiailag a DLBCL-re jellemző; - idős betegek EBV+ DLBCL-je.

Ugyancsak ismert, hogy nem megfelelöen kezelt humán immundeficientiavírus- (HIV-) fertőzés esetén jelentősen megnő a DLBCL incidenciája. Ez a bevezetett „highly active antiretroviral therapy” (HAART) óta jelentősen csökkent. A hepatitis C-vírus (HCV) krónikus fertőzéssel járó eseteiben is előfordulhatnak B-sejtes lymphomák és ritkán DLBCL is.

A krónikus Helicobacter pylori-fertőzés a gyomorban képes B-sejtes proliferációt, majd mucosaasszociált lymphoid szövet (MALT) lymphomát indukálni, amely lassan progrediálva klasszikus DLBCL-t tud létrehozni. A szemben kialakuló primer ocularis DLBCL eseteiben a háttérben Campylobacter-infekciót lehet kimutatni.

A rel, c-myc, bcl2 géneket érintő amplifikáló mutációk a proliferáció elősegítésével szintén szerepet játszanak a DLBCL kialakulásában. A bcl-2 vagy c-myc gén az immunoglobulin-nehézlánc $(\mathrm{IgH})$ gén mellé való transzlokációja $\mathrm{t}(8 ; 14)$ vagy $\mathrm{t}(14 ; 18)$ elősegíti a DLBCL kialakulását. Ugyancsak jelentős a szomatikus hipermutációt elősegítő bcl-6, c-myc, protoonkogén szerin/treonin kináz (PIMl), „paired box protein 5” (PAX5) és ras homológ géncsalád $\mathrm{H}$ (RhoH/TTF) hatása a betegség patogenezisében. A vázoltakon túl, az esetek közel 20\%ában a tumorprotein 53 (TP53) gént érintő mutációk szerepe is fontos.

\section{A DLBCL patomorfológiai jellemzői}

A diffúz nagy B-sejtes lymphoma patológiai, szövettani diagnózisa viszonylag könnyú. A sejtek jellemző morfológiával bíró nagy B-sejtek, viszonylag nagy laza kromatinszerkezetű maggal és jól körülírt, világos citoplazmával. A felszíni CD antigének közül az LCA, CD19, CD20, CD79A és CD22 mutat pozitivitást a legtöbb esetben. Ezen túlmenően számos marker jelen lehet (bcl-6, bcl-2, MUM1, CD10, CD30), amely további alcsoport-meghatározást tesz lehetővé.

\section{Karakterisztikus mutációk és DLBCL-alcsoportok}

Génexpresssziós profilvizsgálatok cluster analízisét végezve a Lymphochip array segítségével a DLBCL 3 csoportba volt sorolható. Az NF-kappa-B útvonal aktivációjával jellemezhető aktivált B-sejtes (ABC) és a centrum germinatívum (GCB) csoport, valamint egy harmadik, nem jellemezhető köztes csoport [1]. Kimutatták, hogy 
a két csoport túlélése eltérő, a GCB-csoport betegeinek 59\%-a, míg az ABC-csoport betegeinek 31\%-a élt 5 évvel a diagnózis után CHOP-kezelést követően [1]. Később az R-CHOP-protokollt használva is igazolható volt ez a különbség. A primer mediastinalis lymphoma esetei is jól elkülöníthetók voltak a Lymphochip array segítségével [2]. Ez az osztályozás nem volt rutindiagnosztikában elvégezhető, ugyanakkor a bemutatott jelentős túlélésbeli különbség mindenképpen igényelte a csoportok megfelelő elkülönítését, ezért Hans és mtsai bevezettek egy immunhisztokémiai módszert, amellyel az ABC-esetek 88\%-os és a GCB-esetek 77\%-os biztonsággal voltak felismerhetők. Az elkülönítésben előforduló bizonytalanság miatt a Hans-algoritmus használata esetén nem az $\mathrm{ABC}$ rövidítést használjuk, hanem a nonGCB (nem centrum germinatívum) megjelölést alkalmazzuk. Az algoritmus a CDl0, bcl-6 és MUMl immunhisztokémiai festések segítségével különíti el a betegeket [3]. Azóta számos szerző vizsgálta a túlélés összefüggését a Hansalgoritmussal, és az adatok nem egyértelmúek. Ennek az az oka, hogy az algoritmus nem tudja 100\%-os biztonsággal elkülöníteni a csoportokat, de még az R-CHOP protokollt használva is egyértelmúen segít a prognózis becslésében [4]. Scott és mtsai 2014-ben közölték, hogy a Lymph2CX GEP-módszert biztonsággal lehet alkalmazni formalinfixált szöveteken, és így biztonsággal el lehet különíteni az ABC és GCB típust [5]. Később egy új prognosztikai modellt is javasolnak, amely a fentiek mellett figyelembe veszi a nemzetközi prognosztikai indexet (IPI) és a bcl-2/myc expressziót [6].

A rituximabbal a DLBCL kezelésében elért eredmények rendkívül biztatóak voltak. Elöször idős betegek CHOP-kezelését egészítették ki rituximab adásával, és már 2 évnél látható volt a progressziómentes túlélési (PFS) elôny [7]. E tanulmány után a DLBCL-betegek kezelésében a rituximab jelentôs szerepet kapott, egyre jobb eredményeket elérve a teljes túlélésben (OS) is. A két karakterisztikus alcsoportot vizsgálva egyértelmúen bizonyítást nyert, hogy a rituximab-CHOP kezeléssel a 3 éves teljes túlélés 52\%-ról 85\%-ra nőtt GCB-esetekben és 33\%-ról 69\%-ra nőtt ABC-esetekben [8], de a különbség megmaradt a két csoport között, bár mértéke kis fokban csökkent a rituximab hatására. Ezeknek az adatoknak a birtokában ma már rutinszerúen vizsgáljuk a betegek alcsoportját, ezzel segítve a prognózisbecslést. $\mathrm{Ez} \mathrm{az}$ információ a relapsus esetén is fontos, mivel a CORAL vizsgálat érdekes eredményt hozott. Addig relapsus esetén az R-ICE- (ifoszfamid, carboplatin, etopozid) vagy R-DHAP- (dexamethason, high-dose AraC, cisplatin) protokollt használtuk. Az adatok elemzése ugyanakkor rávilágított, hogy a GCB-csoportban az RICE eredményei közel 20\%-kal rosszabbak (3 éves PFS $31 \%$ vs. $52 \%)$. Az ABC-csoportban csak $5 \%$ különbség adódott, ami statisztikailag nem szignifikáns. Ez a különbség a teljes túlélésben is mutatkozott a GCB-csoport esetén (51\% vs. $60 \%$ ) [9]. Ez alapján az R-DHAP használata került előtérbe.
Mindezek az adatok egyre jobb prognózisbecslést, egyre hatásosabb kezelést eredményeztek, de még mindig a betegek jelentős része esetén nem tudtunk megfelelő eredményeket elérni.

A Lymphochip vizsgálatok elvégzése elött már vizsgálták a bcl-6-expressziót és annak hatását a DLBCL túlélésére. Azóta tudjuk, hogy a bcl-6 szerepe nagyon fontos a B-sejt-receptor- (BCR-) jelátvitel kezdeti stádiumában a receptorhoz enyhén kötődő antigének esetén. Már 1998-ban felhívta Vitolo a figyelmet a bcl-2-, bcl-6- és c-myc-transzlokációk szerepére közleményében [10]. Igazolta, hogy a bcl-2-t érintő transzlokációvizsgálat önmagában más prognosztikai szereppel bír, mint a bcl-2 protein jelenléte transzlokáció nélkül. Ugyancsak ő volt, aki rávilágított a c-myc-pozitív esetek rossz prognózisára. A double hit lymphomák, amelyekben kettôs genetikai eltérés igazolható (c-myc és bcl-2 vagy bcl-6) elófordulása lymphomatípusonként eltérő, de DLBCLesetekben messze a leggyakoribb. A morfológiai kép legtöbbször a DLBCL NOS-nak felel meg a változatos megjelenés miatt. Nagyon fontos, hogy milyen módszerrel vizsgáljuk a c-myc-eltéréseket a lymphomában. A genetikai eltérés meglétének igazolása (FISH) nem ad pontos segítséget. Tisztázni kell, hogy milyen hatása van a mutációnak. Klinikailag elsősorban az amplifikáció, ami fokozott proteinszinttel jár, jelenti a rosszabb prognózist, míg a többi eset a normálpopulációval közel azonos prognosztikával bír. Ugyancsak fontos elkülöníteni az immunhisztokémiával igazolt fokozott proteinexpressziót olyan esetekben, ahol nincs kimutatható mutáció. Ezeknek az eseteknek a száma lényegesen nagyobb (2-2,5-szer több), mint a mutációt hordozó eseteké, mivel itt más myc-szabályozást befolyásoló elemek eltérései okozzák a fokozott proteinexpressziót, és a prognózis nem feltétlenül rosszabb. Fontos megfigyelés, hogy a myc-pozitív lymphomák esetén a GEP-profil alapján két nagyon eltéró prognosztikájú csoport azonosítható. A Burkitt-lymphomaszerú profillal rendelkező esetek prognózisa lényegesen jobb, mint a többi eseté, annak ellenére, hogy a myc-expresszió fokozott. Ennek részben az az oka, hogy a Burkitt-típusú betegségben többnyire csak myc-expresszió van, míg a többi eset valódi „double" és "triple hit” lymphoma [11]. Az összes double hit lymphoma egyharmada DLBCL-eset, ami az eltérés jelentőségére felhívja a figyelmet. Kimutatták, hogy a GCB és $\mathrm{ABC}$ altípuson belül a double hit eltérés jelentős túlélésbeli különbségeket eredményez. Ha a bcl-2-transzlokáció jelen van a GCB-csoportban, akkor a túlélés az ABC-csoporthoz hasonlóan rossz lesz. Ezt tovább rontja minden esetben, ha „double hit” eltérés igazolódik, ekkor a betegek medián túlélése alig 24 hónap [12]. Egy másik munkacsoport a bcl-2 és myc fehérje expresszióját vizsgálva próbálta az eseteket vizsgálni. Bcl-2 esetén 30\% és myc esetén $50 \%$ cut-off értéket választva élesen elkülöníthető volt a betegek teljes (OS) és eseménymentes (PFS) túlélése. Míg bcl-2- és myc-negatív esetekben az 5 éves OS $100 \%$ volt, a kettős proteinexpresszáló esetek- 
ben ez 45\%. Még érdekesebb, ha adataikat a GCB- és ABC-csoportokban külön vizsgálták, mivel mindkét csoportban a kettős negatív esetek 5 éves túlélése 100\%, míg a kettős pozitív esetek esetén a GCB-csoportban és az ABC-csoportban is $45 \%$ körüli túlélés igazolható [13]. A fentieken kívül még több szerző publikálta adatait a double hit lymphomák kezelésével kapcsolatban és megállapítható, hogy R-CHOP-vázas kezelés alkalmazása esetén a PFS és OS rosszabb a double hit esetekben [14]. Ugyanakkor R-DA-EPOCH (dózisadaptált rituximab, etopozid, ciklofoszfamid, vincristin, adriablastin, prednisolon) alkalmazása esetén a hátrány lecsökken nem szignifikáns mértékre [15]. Az alcsoportokat vizsgálva az is igazolódott, hogy a relabáló/refrakter myc-pozitív DLBCL kezelésében standard R-ICE/R-DHAP salvage és R-BEAM-transzplantáció nem ad megfelelő eredményt [16]. Érdekes új adat az addicionális TP53-mutáció jelenléte, amely a doble hit lymphoma esetén képes ellensúlyozni a kedvezőtlen prognosztikát. Ugyanakkor izolált TP53-mutáció rossz prognosztikával bír [17].

A DLBCL etiológiájában a fenti mutációkon kívül további eltérések kerültek leírásra. Az ABC-alcsoportra jellemző a folyamatos NF-kappa-B-aktiváció, amelynek fenntartásáért több tényező felelős. Már 2008-ban azonosították a CARD1 l-mutációt, amely a jelátviteli úton a Bruton-tirozinkináz (Btk) alatt helyezkedik el, ezáltal beszúkíti a terápiás lehetőségeket [18]. A mutáció egyenlő arányban fordul elő GCB és ABC típusban. Ugyancsak jelentős szereppel bír a MYD88-mutáció, amely a Toll-receptorok downstream útvonalában található és elsősorban az ABC típusban fordul elő [19]. Ez magyarázza, hogy speciális immunprivilegizált helyeken levő DLBCL-ek esetében nagy százalékban (akár 75\%) fordul elő (agyi DLBCL, here-DLBCL, speciális extranodalis DLBCL) [20]. A szoros asszociáció a Toll-receptorokkal felveti a környezeti szignálok, PRP-k (pattern recognition peptide) szerepét a lymphoma kialakulásában is. A hatásához szükséges a CD19 és a Btk-n keresztül közvetíti a sejtmagba a proliferációs szignált.

A ma már könnyen elérhető next generation sequencing (NGS) technikát alkalmazva a DLBCL-eseteket vizsgálva számos újabb, valószínúleg fontos szereppel bíró mutációt is azonosítottak (mTOR, PI3K, MEF2B, ARIDlA, WIFl), amelyek pontos szerepét még tisztázni kell [21]. Az epigenetikus szabályozás szerepe is egyértelmű, hiszen igazolták, hogy magas EZH2-szintek egyértelmúen jobb túléléssel társultak. Az epigenetikus szabályozás szerepe egyre fontosabb a patogenezis pontos megismerésében. A hiszton $\mathrm{N}$ terminális részén levő lizin és arginin aminosavak metilációja a kromatint „összezárja”, a tárolt információ nem lesz elérhető. Ugyanakkor az N terminális lizinek acetilációja csökkenti a pozitív töltést, ami a tárolt nukleinsav lazább kötését eredményezi, elérhetővé válik a rajta tárolt kód. Ez a metiláció/demetiláció és acetiláció/deacetiláció egy nagyon finoman szabályozott rendszer.
Az immunrendszer szerepe is egyre jobban igazolódik a DLBCL prognózisában. A PD-1L expresszáló esetekben hatásos ennek blokkolása. Ugyancsak fontos a HLAII-expresszió-csökkenés a tumorsejteken, amely egyértelműen rosszabb prognózist jelez. Ugyancsak ismert, hogy a keringő vérben a lymphocyták/monocyták aránya prognosztikai szereppel bír. Igazolódott, hogy a keringő CD8+ lymphocyták számának csökkenése kedvezötlen prognosztikát jelez.

Mindezen adatok alapján ma már nagy kihívás előtt állunk, hiszen számos új patológiai és molekuláris biológiai módszerrel egyre pontosabb karakterizálása lehetséges a betegségnek, amely a növekvő terápiás lehetőségeket figyelembe véve új kihívásokat jelent.

A tumorsejtek megfelelő karakterizálása, a felszíni adhéziós molekulák, kemokinreceptorok megléte vagy hiánya előre tudja jelezni, hogy a betegség mely szervekbe képes terjedni. Ez a rendkívül fontos megállapítás a közeli jövőben megváltoztathatja a kezelési stratégiát, része lehet a prognosztikának.

\section{A DLBCL kezelése ma}

Az előzőleg vázolt adatok ismeretében a DLBCL kezelése egyre nehezebb, ha igyekszünk minden prognosztikai faktort figyelembe venni. Ma a kezelést elsősorban a rendelkezésre álló, törzskönyvezett készítmények és az elérhető fázis II-III. vizsgálatok határozzák meg.

A kezelés célja az arra alkalmas betegekben a komplett metabolikus remisszió (KMR) és teljes tünetmentesség elérése. A PR nem tekinthető terápiás sikernek. Komplett remisszió akkor igazolható, ha legalább 6 hónapig a kezelést követően nem jelentkezik relapsus, ellenkező esetben refrakter betegségról kell beszélni. A legújabb adatok alapján, rituximabtartalmú kezelés esetén, ha a kezelést követő 24 hónapban nem jelentkezik relapsus, akkor a betegség prognózisa nagyon jó (EFS24-érték) [22].

A diagnózist mindenképpen szövettani vizsgálattal kell igazolni, ami lehet sebészi excisio vagy core-biopszia. A patológiai diagnózis ma már tartalmazza a GCBés non-GCB- (ABC-) csoportba sorolást. Ezen túlmenően a bcl-6-, bcl-2-expressziót is. Többnyire jellemző morfológia van a myc-pozitív esetekben, így gyanú esetén ez is elvégezhető. Ezt követően a pontos staging indokolja a megfelelő képalkotó vizsgálatok elvégzését. A ${ }^{18}$ FDG-PET/CT szükséges minden esetben, mivel csak ezzel lehet a pontos Lugano klasszifikációt elvégezni. Ha ez nem elérhető, 4 régió (nyak-mellkas-has-medence) kontrasztos CT-vizsgálata javasolt. A CT-nél pontosabb információt szolgáltat a teljestest-MRI, amely azonban még nem terjedt el rutinszerúen.

Fontos tisztázni a beteg komorbiditásait, és hepatitisszerológiákat kell venni. Amennyiben felmerül hepatitis B-fertőzés (HBsAg-pozitív vagy anti-HBc-pozitív), akkor antivirális profilaxist kell alkalmazni [23]. A vírusDNS monitorozása is javasolt alacsony rizikó esetén, de 
bizonyítottan nem annyira hatásos a kezelés elkezdése emelkedő vírustiter esetén, mint ha profilaxist kapott volna a beteg [23]. A hepatitis C-pozitív esetekben szintén indokolt vírus-RNS-PCR, de a reaktiváció veszélye $\mathrm{C}$-vírus esetén nem annyira jelentős.

A kezelés előtt meg kell határozni a beteg klinikai stádiumát (ECOG PS vagy Karnofsky), a pontos módosított Ann Arbor stádiumot. A legújabb Lugano klasszifikáció használata ajánlott, tehát nem szükséges a $B$ tüneteket rögzíteni, ugyanakkor a PET/CT alapján $\mathrm{D}_{\max }{ }^{-}$és $S U V_{\max }$-értékek rögzítése is indokolt, javasolt [24].

A prognózis meghatározása az IPI (nemzetközi prognosztikai index) és R-CHOP esetén az R-IPI alapján történik [25]. A rituximab alkalmazásával a hagyományos IPI statisztikai ereje lényegesen csökkent [26]. Az R-IPI 3 prognosztikai csoportot különít el az alkalmazott 5 paraméter (életkor, LDH-érték, Ann Arbor stádium, ECOG PS, extranodalis érintettség) alapján. Az eredmények az R-CHOP21-kezeléssel lettek validálva és egyértelmúen meghatározzák a prognózist. Megfigyelhető, hogy azon DLBCL-betegek, akiknek betegsége a rituximabkezelést követő 24 hónapban nem újul ki, már nagy valószínúséggel gyógyultnak tekinthetők. Emiatt egy újabb provizórikus prognosztikai rendszert, az IPI24 bevezetését javasolják, amely ezt jól előre tudja jelezni. Az IPI24-ben használt változók: az életkor, az LDH, az abszolút lymphocytaszám, az Ann Arbor stádium, ECOG PS, a 10 cm-nél nagyobb bulky és a nem [27].

A DLBCL első vonalbeli kuratív célzatú kezelésének az alapja az R-CHOP21-protokoll [28]. Minden arra alkalmas beteg esetén ennek alkalmazása javasolt. Amenynyiben megfelelő klinikai válaszadás van, akkor az 5 . ciklus előtt elég indokolt interim vizsgálatok végzése. Itt elsősorban a ${ }^{18} \mathrm{FDG} \mathrm{PET} / \mathrm{CT}$ jön szóba, mivel a metabolikus választ is jól detektálja residuumok esetében [29]. (Korábban már a 2. ciklus után javasoltak vizsgálatot, de ez rutinszerúen nem javasolt a késői reagálók miatt. Természetesen indokolt esetekben ez elvégezhető.) Amennyiben nem elérhető a PET/CT vizsgálat, akkor konvencionális kontrasztos $\mathrm{CT}$ végezhető, de ennek értékelése néha nehéz a residuumok mérete miatt. Összesen maximum 8 ciklus alkalmazása indokolt, de kis rizikójú betegség esetén 6 ciklus kezelés elegendő lehet. Ilyenkor is javasolt azonban még a további 2 ciklus rituximab alkalmazása. Ha kellő tapasztalat és gyakorlat rendelkezésre áll, akkor lehet R-CHOP14-protokollt is alkalmazni, amelyből 6 ciklus is elegendő, de javasolt a +2 ciklus rituximab alkalmazása. Amennyiben a kiindulási betegség bulky jellegű volt, akkor javasolt a kemoterápia végén a kiindulási bulky terület involved field (IF) irradiációja csökkentett dózissal (30-36 Gy). Az agresszív, nagy rizikójú csoportba tartozó (IPI) betegek esetén az első vonalbeli kemoterápia után indokolt lehet az autológ csontvelő-transzplantáció elvégzése is, mivel egy viszonylag új tanulmány alapján a 2 éves OS transzplantációval 82\%, míg transzplantáció nélkül csak 64\% [30].
Ugyancsak indokolt a rossz prognosztikával bíró double és triple hit esetek első vonalbeli transzplantációja is. Ettôl eltérni az alábbi esetekben indokolt:

Igazoltan I/A stádium esetén (vagy idős betegekben komorbiditások esetén II/A stádiumban is) lokális sugárkezelést (maximum $36 \mathrm{~Gy}$ ) lehet alkalmazni. (Ez esetben feltétlenül indokolt a pontos staging PET/CTvel, és el kell végezni a csontvelővizsgálatot is a tévesen korai stádiummegállapítás kizárására.)

Primer mediastinalis B-sejtes lymphoma (PMBL) esetén R-CHOPl4-protokoll alkalmazásával jobb eredmények vannak, de ezeknél a betegeknél a mediastinum irradiációja szóba jön. (Most folynak vizsgálatok arra vonatkozóan, hogy az irradiációt el lehet-e hagyni.) A legújabb adatok alapján ezeknél a betegnél az R-DA-EPOCH kezelés ajánlott, amely után nem kell irradiációt végezni [31]. Ebben a csoportban a magas PDIL-expresszió miatt nagyon hatásos salvage kezelés lehet a PDl-gátlók alkalmazása. Fontos külön megemlíteni a ritka, de fontos klinikai jelentőségű szürkezónalymphomát, amely a PMBL és a klasszikus nodularis sclerosis Hodgkin-lymphoma közötti átmeneti jelekkel bír, mivel prognózisa sokkal rosszabb. Ezekben az esetekben az agresszívebb kezelések használata indokolt mindenképpen (R-DA-EPOCH) [32].

High risk, double és triple hit lymphoma agresszív indukciós kezelést igényel. Itt nincs konszenzus, de a publikált adatok alapján R-DA-EPOCH mindenképpen megfontolandó [15]. Ezen túl lehetséges RHyperCVAD/R-MA vagy R-CODOX-M/R-IVAC alkalmazása is mindig egyéni megfontolás alapján. Jelen kezelési lehetőségek mellett ezeknél a betegeknél első vonalbeli autológ csontvelő-transzplantáció is mérlegelendő és javasolható.

Intrathecalis profilaxist indokolt adni a kezelésekhez minden herelymphoma, ocularis lymphoma és emlőlymphoma esetén. Egyéb, jelentős extranodalis érintettséget adó lymphomák esetén az intrathecalis profilaxis egyéni mérlegelést igényel.

Gyomoreredetű DLBCL esetén az immunokemoterápián túl Helicobacter pylori eradikációs kezelés alkalmazása is indokolt minden esetben. Korai stádiumban csak eradikáció és szoros követés is elegendő lehet.

A központi idegrendszeri lymphoma kezelése speciális megfontolást igényel. Az R-MPV (rituximab, metorexát, procarbazin, vincristin) 2 hetente alkalmazva, majd fiatalabb betegeken a Thiotepa-Busulfan-Cytoxan kondicionálással autológ őssejttranszplantáció nagyon biztató eredményeket mutat, mivel 2 évnél az OS 80\% és platót képez [33]. A rituximab nagy dózisú $\left(3,5 \mathrm{~g} / \mathrm{m}^{2}\right)$ metotrexát adásával még egészen idős, akár 90 éves betegekben is biztonsággal alkalmazható. Ugyancsak alkalmazható első vonalban a metotrexát/AraC kombináció rituximabbal, de ez után is mindenképpen indokolt az autológ transzplantáció [34]. A metotrexát alkalmazása ma már a rapid formában indokolt, tehát nem a klasszi- 
kus 24 órás infúzió, hanem 4-6 órás infúzió javasolt 24 órás ablakkal a folinsavkezelés elkezdése előtt.

Idős betegek esetén az EBV + DLBCL altípus igazolása rossz prognózist sejtet. Ennek az altípusnak a kezelésére nem kellően hatásos az R-CHOP-protokoll. A hatásos kezelést még keressük, nincs kellő evidenciával rendelkező ajánlás. A biológiailag fitt betegek esetén meg kell próbálni erélyesebb kezelést alkalmazni (R-EPOCH).

Minden esetben az első vonalbeli kezelés végén, az utolsó kezeléstől minimum 6 hétre indokolt ${ }^{18} \mathrm{FDG}$ PET/CT végzése. A Lugano kritériumoknak megfelelő komplett remisszió csak megfeleló PET/CT ismeretében mondható ki [24]. Ez különösen a bulky kiindulási tumorterületek megfelelő értékeléséhez elengedhetetlen [35].

A visszaeső és első vonalbeli kezelésre refrakter esetek mindenképpen mentő kezelést (salvage) igényelnek. Ahogy korábban írtuk, elsősorban az R-DHAP alkalmazása javasolt [9]. Amennyiben a beteg életkora és komorbiditása lehetővé teszi, akkor lehetőleg autológ transzplantációt kell ilyenkor tervezni. Ma a transzplantációt 70 éves korig lehet elvégezni arra alkalmas betegeken [36]. Amennyiben az első R-DHAP-kezelésre jól reagált, már a 2. R-DHAP során indokolt az őssejtgyüjtés elvégzése. Ezt követően a beteget addig kell kezelni, míg ${ }^{18}$ FDG-PET/CT negatív lesz és csak ekkor indokolt a transzplantáció elvégzése [37]. A PET+ esetek transzplantációja nem javasolt rutinszerúen, mivel a túlélési eredmények lényegesen rosszabbak [37].

A salvage kezelésre nem reagáló betegek kezelése nehéz. Itt elsősorban klinikai tanulmányban való részvétel javasolt, és amennyiben sikerült kemoszenzitivitást, remissziót elérni, javasolt az autológ őssejt-transzplantáció elvégzése.

A rutinszerúen elérhető gyógyszerek közül elsősorban a bendamustin, gemcitabin és pixantron alkalmazása jön szóba, de ezzel már nem várható tartós remisszió, inkább tartósabb PR biztosítása lehet, ezért ezeknek a betegeknek a kezelése a közeli jövő új gyógyszereivel lesz valószínúleg lehetséges, amit a következő részben ismertetünk [38].

\section{A DLBCL kezelésének lehetőségei a közeli jövőben ${ }^{1}$}

A DLBCL első vonalbeli kezelését az R-CHOP forradalmasította, de még mindig jelentős számú (a betegek közel $40 \%$-a) beteg esetén nem ad tartós gyógyulást. A rituximab helyett a 3 . generációs obinutuzumab (GAZYVA) anti-CD20 hatását vizsgálta a BO21005 Goya fázis III. klinikai vizsgálat, amelynek végleges eredményei még nem állnak rendelkezésre. Az obinutuzumab egy II. típusú „glikoengineered” monoklonális an-

A leírt kezelések a kézirat leadásakor off-label alkalmazások! titest, sokkal erósebb antitestdependens sejt mediálta citotoxikus (ADCC) és direkt tumorölö hatással.

Korábban vizsgálták, hogy az NF- $\kappa \mathrm{B}$-aktivációval járó ABC-altípusban az R-CHOP helyett bortezomib + R-CAP kerül alkalmazásra. A vizsgálat eredményei nem igazolták a várt hatást, nem tudtak előnyt kimutatni az EFS és OS esetén a bortezomib alkalmazásával [39].

Az ABC altípusú DLBCL esetén igen jelentős, folyamatos B-sejt-receptor-aktiváció van, amely a kaszkádon végighaladva végül is tartós $\mathrm{NF}-\kappa \mathrm{B}$-aktivációt okoz. A folyamat kezdeti szakaszának fontos résztvevője a Bruton-tirozinkináz (Btk). Az ibrutinib (IMBRUVICA) irreverzibilis kovalens kötéssel kötődik a Btk-hoz, gátolva ezzel a B-sejt-receptor felől érkező aktivációs szignált. A gátlás a sejtek proliferációját leállítja, nem érzékelik a környezeti szignálokat és apoptózis folyamata indul meg. Az előkísérletek alapján ABC DLBCL esetén jelentős hatással bír. A DA-EPOCH kezeléshez adott ibrutinib közel duplájára emelte a túlélést az ABC-csoportban, de a GCB-altípusban az eredmények nem szignifikánsan romlottak. Ezért az alkalmazás feltétele a pontos klasszifikáció [40]. Az előzetes adatok alapján a DBL3001 Phoenix fázis III. klinikai vizsgálat első vonalban vizsgálta az R-CHOP-hoz adott ibrutinib hatását. Az adatok még nem állnak rendelkezésre.

Igazolták, hogy a DLBCL egyes eseteiben jelentős epigenetikus szabályozási zavarok vannak, elsősorban az EZH2, a hiszton-lizin-N-metil-transzferáz 2A (KMT2A) eltéréseit mutatták ki [41]. Biztató előkísérletek vannak a vorinostat alkalmazásával, de más hisztondeacetiláz-gátlók (HDACi) alkalmazásának lehetőségét is vizsgálják. A belinostat alkalmazásával is vannak kedvező kezdeti tapasztalatok B-sejtes lymphomák esetén is. A HDACi alkalmazása szinergizmust mutat a hipometiláló decitabin alkalmazásával is, ami szintén új terápiás lehetőség lehet a jövőben.

A myelomában elért kedvező hatások alapján az imidek egyre nagyobb jelentőségüek a lymphomák kezelésében is. $\mathrm{Az} \mathrm{R}^{2}$-CHOP ( $\mathrm{R}-\mathrm{CHOP}+$ lenalidomid 25 mg) alkalmazásával az ABC-csoportban a 2 éves túlélés 46\%-ról 83\%-ra nőtt. Ez a különbség nem látható a GCB-csoportban [42]. Ezen adatok alapján az ABC-altípus kezelésében a lenalidomid alkalmazása mindenképpen szóba jön. Visszaeső és refrakter DLBCL kezelésében a Lenalidomid + R-ESHAP protokoll kedvező eredményeket adott, CR: 47,4\%, CR+PR: 78,9\%. A 2 éves eseménymentes túlélés (EFS) 44\% és a teljes túlélés (OS) 63\% [43]. Az alkalmazott lenalidomiddózis 5-15 $\mathrm{mg} /$ nap 21 napig 3 ciklusban.

Az mTOR-gátló everolimus számos preklinikai vizsgálatban hatásos szinergizmust mutatott rituximabkezeléssel DLBCL esetén. Klinikai tanulmányokban előkezelt, refrakter DLBCL esetén is mutatott hatást az everolimus/rituximab kombinációs kezelés egy viszonylag kedvező mellékhatásprofil mellett [44]. A kedvezőtlen mellékhatásprofillal bíró temsirolimus és bendamustin- 
rituximab kombinációja hatásosnak tûnik visszaeső DLBC esetén publikált esettanulmány alapján.

A felszíni CD22-ellenes monoklonális antitest, epratuzumab alkalmazásáról egy kedvező eredménnyel zárult fázis II. vizsgálat számolt be. 36 hónapot követően mind az EFS, mind az OS kisfokban kedvezőbb az epratuzumab-R-CHOP (ER-CHOP) betegek esetében összehasonlítva az R-CHOP-kezeléssel [45]. Tekintettel arra, hogy azóta számos újabb kezelési lehetőség jelent meg, a további vizsgálatok háttérbe szorultak.

A felszíni CD19 molekula ellenes genetikailag módosított anti-CD19 (MOR00208) antitest alkalmazásával folynak vizsgálatok relabáló/refrakter DLBCL esetén mind monoterápiában, mind kombinációs kezeléssel (lenalidomid, rituximab-bendamustin) kombinálva. Az eredmények nem állnak rendelkezésre a kézirat lezárásakor.

A DLBCL jelentôs hányada, akár 30\% pozitív lehet a felszíni CD30 antigénre. Fázis II. klinikai vizsgálatban refrakter/relabáló DLBCL esetén a brentuximab vedotin (ADCETRIS) monoterápia kedvező eredményeket mutatott [46]. Az eredmények alapján további vizsgálatok indulnak a brentuximab vedotin kombinációs kezelés alkalmazásával DLBCL első vonalban is. Ez szintén alkalmas lehet a visszaeső CD30+ betegség hatásos kezelésében.

Visszaeső és nem reagáló DLBCL-betegekben vizsgálták a bispecifikus T-sejt-kötő blinatumomab (BLINCYTO) hatását. Az eredmények biztatóak, így lehetséges, hogy ez a kezelés is alkalmazható lesz a későbbiekben [47]. A gyógyszer alkalmazása folyamatos subcutan infúziót igényel.

A dacetuzumab (anti-CD40) visszaeső/refrakter DLBCL-ben alkalmazva viszonylag szerény eredményeket ért el, ezért fontos a megfelelő kezelési kombinációk keresése, ha tartós hatást kívánunk elérni [48].

$\mathrm{Az}$ utóbbi években jelentős előrelépés történt az immune-checkpoint inhibitorok terén. A tumorsejtek által termelt és felszínen expresszált PD-1L (és PD-2L) képes az immunrendszert tolerogén állapotban tartani a T-sejten levő PD-1-hez kapcsolódva. Ezt a kapcsolatot megzavarva monoklonális antitestekkel, jelentős reagálást lehet elérni. Ezt fokozza a T-sejtek felszínén levő OX40 (CD134) receptorhoz való kötődés, amely erősíti a Tsejtes immunválaszt. Szintén gátlóhatást közvetít a T-sejten levő CTLA-4 (CD152) receptorhoz kötődés. Ezek a molekulák jelentős mértékben képesek az immunválaszt befolyásolni. DLBCL esetén ez a hatás nem jelentős, a betegek egy kisebb része (körülbelül 20-30\%-a) reagál, de ezekben az esetekben jelentős hatást lehet elérni, a PD-1L-expresszió ezért prognosztikai jelentőséggel is bír. A PDI-hez kötődő pidilizumab alkalmazásával már vannak biztató előkísérletek és folyamatban van további klinikai vizsgálat. Ugyancsak vizsgálják a nivolumab, pembrolizumab, ipilimumab, atezolimumab, urelumab hatását, többnyire még fázis I. vizsgálatokban.
A polatuzumab vedotin (anti-CD79B-hez kötött monometil auristatin) alkalmazásával biztató előkísérleti eredmények vannak. A fázis I. vizsgálatban B-sejtes lymphomákban jó hatásosság mutatkozott, most indul a fázis II. klinikai vizsgálat az alkalmazásával [49].

Hasonló hatású a pinatuzumab vedotin (anti-CD22höz kötött monometil auristatin), aminek hatását a ROMULUS fázis II. klinikai vizsgálat eredményei támasztották alá [50].

Az NGS egyre szélesebb körű elterjedése a vizsgálat költségeinek jelentős csökkenését eredményezi, és egyre több betegséget vizsgálva növekszik az ismeretanyag. A fentebb vázolt számos új kezelés esetén már indokolt a betegségben jelen lévő mutációk ismerete, vizsgálata. Vannak már arra próbálkozások, hogy diagnóziskor alkalmazott NGS alapján próbáljuk meg kiválasztani a lehetséges kezelést.

A vázolt, elsősorban tanulmányokban folytatott kezelések eredményei biztatóak, de itt még elsősorban reagálás, remissziók és rövid követési idők alatt elért túlélések láthatóak. Tartósabb remissziók vizsgálatához még többéves követési idők szükségesek. Nem tudjuk, hogy ezek a kezelések önmagukban képesek-e meggyógyítani a betegséget vagy csak egy betegségmentes időszakot eredményeznek. Ez nagyon fontos információ, hiányában a beteg megfelelő kezelése biztonsággal nem tervezhető. Ezért ma minden arra alkalmas betegnél, akinél remissziót sikerült elérni, indokolt az autológ csontvelőtranszplantáció lehetőségének a mérlegelése.

\section{További kérdések a DLBCL kezelésével kapcsolatban}

A fentebb vázolt standard és jövőben elérhető kezelésekkel egyre pontosabban ki tudjuk választani a beteg részére leghatásosabb kezelést. Ez előtérbe helyezi a kezelés késői toxicitásainak a figyelését is. Egyre hangsúlyosabban fog megjelenni a közeljövő kezeléseiben a kezeléssel járó toxicitás és késői toxicitások követése, hogy lehetőleg a beteg életminőségét a lehető legkevésbé befolyásolja a ma már egyre jobban gyógyítható betegsége.

Nem tértünk ki részletesen az indolens lymphomáknál már többnyire rutinszerúen alkalmazott fenntartó kezelés alkalmazására. Rituximab fenntartó kezelés alkalmazásával vannak kedvező és kedvezőtlen eredmények. Egyéb - jelentôs toxicitással nem bíró - ágensek fenntartó kezelésben való használata még nincs vizsgálva, várhatóan a közeli jövőben fog erról több információ rendelkezésre állni. Az újabb gyógyszerek tartósan szájon át is alkalmazhatók, ami felveti, hogy alkalmazásuk nem szükséges-e tartósabban, akár mint egy fenntartó kezelés. Valószínúleg a válaszhoz ki kell választani a rossz prognózisú betegeket és náluk kell azt vizsgálni, hogy a jól reagáló/gyógyuló betegeket tartósan ne tegyük ki a folyamatos kezelés/gyógyszerszedés okozta hátrányoknak. Ezenkívül bizonyítani kell a gyógyszer tartós szedésének a biztonságosságát is. 
A ${ }^{18}$ FDG-PET/CT egyre kiterjedtebb használata lehetôvé teszi a terápia hatásának a nagyon pontos követését. Korán, jól reagáló betegek esetén felmerül a terápia tartamának csökkentése, így a toxicitás is jelentősen csökkenhet. Ennek a kérdésnek a megválaszolása további nagy betegszámon végzett klinikai vizsgálatot igényel.

Anyagi támogatás: A közlemény megírása anyagi támogatásban nem részesült.

Szerzői munkamegosztás: G. L.: A kézirat elkészítése. I. Á.: A kézirat átolvasása és javítása. A cikk végleges változatát mindkét szerző elolvasta és jóváhagyta.

Anyagi érdekeltségek: A szerzőknek nincsenek érdekeltségeik.

\section{Irodalom}

[1] Wright, G., Tan, B., Rosenwald, A., et al.: A gene expressionbased method to diagnose clinically distinct subgroups of diffuse large B cell lymphoma. Proc. Natl. Acad. Sci. U.S.A., 2003, 100(17), 9991-9996.

[2] Rosenwald, A., Wright, G., Leroy, K., et al.: Molecular diagnosis of primary mediastinal B cell lymphoma identifies a clinically favorable subgroup of diffuse large B cell lymphoma related to Hodgkin lymphoma. J. Exp. Med., 2003, 198(6), 851-862.

[3] Hans, C. P., Weisenburger, D. D., Greiner, T. C., et al.: Confirmation of the molecular classification of diffuse large B-cell lymphoma by immunohistochemistry using a tissue microarray. Blood, 2004, 103(1), 275-282.

[4] Visco, C., Li, Y., Xu-Monette, Z. Y., et al.: Comprehensive gene expression profiling and immunohistochemical studies support application of immunophenotypic algorithm for molecular subtype classification in diffuse large B-cell lymphoma: a report from the International DLBCL Rituximab-CHOP Consortium Program Study. Leukemia, 2012, 26(9), 2103-2113.

[5] Scott, D. W., Wright, G. W., Williams, P. M., et al.: Determining cell-of-origin subtypes of diffuse large B-cell lymphoma using gene expression in formalin-fixed paraffin-embedded tissue. Blood, 2014, 123(8), 1214-1217.

[6] Scott, D. W., Mottok, A., Ennishi, D., et al.: Prognostic significance of diffuse large B-cell lymphoma cell of origin determined by digital gene expression in formalin-fixed paraffin-embedded tissue biopsies. J. Clin. Oncol., 2015, 33(26), 2848-2856.

[7] Coiffier, B., Lepage, E., Briere, J., et al.: CHOP chemotherapy plus rituximab compared with CHOP alone in elderly patients with diffuse large-B-cell lymphoma. N. Engl. J. Med., 2002, $346(4), 235-242$.

[8] Fu, K., Weisenburger, D. D., Choi, W. W., et al.: Addition of rituximab to standard chemotherapy improves the survival of both the germinal center B-cell-like and non-germinal center B-celllike subtypes of diffuse large B-cell lymphoma. J. Clin. Oncol., 2008, 26(28), 4587-4594.

[9] Thieblemont, C., Briere, J., Mounier, N., et al.: The germinal center/activated B-cell subclassification has a prognostic impact for response to salvage therapy in relapsed/refractory diffuse large B-cell lymphoma: a bio-CORAL study. J. Clin. Oncol., 2011, 29(31), 4079-4087.

[10] Vitolo, U., Gaidano, G., Botto, B., et al.: Rearrangements of bcl-6, bcl-2, c-myc and 6q deletion in B-diffuse large-cell lymphoma: clinical relevance in 71 patients. Ann. Oncol., 1998, 9(1), 5561 .
[11] Caponetti, G. C., Dave, B. J., Perry, A. M., et al.: Isolated MYC cytogenetic abnormalities in diffuse large B-cell lymphoma do not predict an adverse clinical outcome. Leuk. Lymphoma, 2015, 56(11), 3082-3089.

[12] Visco, C., Tzankov, A., Xu-Monette, Z. Y., et al.: Patients with diffuse large B-cell lymphoma of germinal center origin with BCL2 translocations have poor outcome, irrespective of MYC status: a report from an International DLBCL rituximab-CHOP Consortium Program Study. Haematologica, 2013, 98(2), 255-263.

[13] Perry, A. M., Alvarado-Bernal, Ү., Laurini, J. A., et al.: MYC and BCL2 protein expression predicts survival in patients with diffuse large B-cell lymphoma treated with rituximab. Br. J. Haematol., 2014, 165(3), 382-391.

[14] Green, T. M., Nielsen, O., de Stricker, K., et al.: High levels of nuclear MYC protein predict the presence of MYC rearrangement in diffuse large B-cell lymphoma. Am. J. Surg. Pathol., 2012, 36(4), 612-619.

[15] Dunleavy, K.: Aggressive B cell lymphoma: optimal therapy for MYC-positive, double-hit, and triple-hit DLBCL. Curr. Treat. Options Oncol., 2015, 16(12), 58.

[16] Cuccuini, W., Briere, J., Mounier, N., et al.: MYC+ diffuse large B-cell lymphoma is not salvaged by classical R-ICE or R-DHAP followed by BEAM plus autologous stem cell transplantation. Blood, 2012, 119(20), 4619-4624.

[17] Schiefer, A. I., Kornauth, C., Simonitsch-Klupp, I., et al.: Impact of single or combined genomic alterations of TP53, MYC, and BCL2 on survival of patients with diffuse large B-cell lymphomas: A retrospective cohort study. Medicine (Baltimore), 2015, 94(52), e2388

[18] Lenz, G., Davis, R. E., Ngo, V. N., et al.: Oncogenic CARDl1 mutations in human diffuse large B cell lymphoma. Science, 2008, 319(5870), 1676-1679.

[19] Wang, J. Q., Jeelall, Y. S., Beutler, B., et al.: Consequences of the recurrent MYD88(L265P) somatic mutation for B cell tolerance. J. Exp. Med., 2014, 211(3), 413-426.

[20] Kraan, W., Horlings, H. M., van Keimpema, M., et al.: High prevalence of oncogenic MYD88 and CD79B mutations in diffuse large B-cell lymphomas presenting at immune-privileged sites. Blood Cancer J., 2013, 3(9), el39.

[21] Zhang, J., Grubor, V., Love, C. L., et al.: Genetic heterogeneity of diffuse large B-cell lymphoma. Proc. Natl. Acad. Sci. U.S.A., 2013, 110(4), 1398-1403.

[22] Maurer, M. J., Ghesquières, H., Jais, J. P., et al.: Event-free survival at 24 months is a robust end point for disease-related outcome in diffuse large B-cell lymphoma treated with immunochemotherapy. J. Clin. Oncol., 2014, 32(10), 1066-1073.

[23] Pattullo, V.: Hepatitis B reactivation in the setting of chemotherapy and immunosuppression - prevention is better than cure. World J. Hepatol., 2015, 7(7), 954-967.

[24] Cheson, B. D., Fisher, R. I., Barrington, S. F., et al.: Recommendations for initial evaluation, staging, and response assessment of Hodgkin and non-Hodgkin lymphoma: the Lugano classification. J. Clin. Oncol., 2014, 32(27), 3059-3068.

[25] Vaidya, R., Witzig, T. E.: Prognostic factors for diffuse large Bcell lymphoma in the $\mathrm{R}(\mathrm{X}) \mathrm{CHOP}$ era. Ann. Oncol., 2014, 25(11), 2124-2133.

[26] Bari, A., Marcheselli, L., Sacchi, S., et al.: Prognostic models for diffuse large B-cell lymphoma in the rituximab era: a never-ending story. Ann. Oncol., 2010, 21(7), 1486-1491.

[27] Maurer, M. J., Jais, J. P., Ghesquières, H., et al.: Personalized risk prediction for event-free survival at 24 months in patients with diffuse large B-cell lymphoma. Am. J. Hematol., 2016, 91(2), 179-184.

[28] Ghielmini, M., Vitolo, U., Kimby, E., et al.: ESMO Guidelines consensus conference on malignant lymphoma 2011 part 1: diffuse large B-cell lymphoma (DLBCL), follicular lymphoma (FL) and chronic lymphocytic leukemia (CLL). Ann. Oncol., 2013, 24(3), 561-576. 
[29] Barrington, S. F., Mikbaeel, N. G., Kostakoglu, L., et al.: Role of imaging in the staging and response assessment of lymphoma: consensus of the International Conference on Malignant Lymphomas Imaging Working Group. J. Clin. Oncol., 2014, 32(27), 3048-3058.

[30] Stiff, P. J., Unger, J. M., Cook, J. R., et al.: Autologous transplantation as consolidation for aggressive non-Hodgkin's lymphoma. N. Engl. J. Med., 2013, 369(18), 1681-1690.

[31] Dunleavy, K., Pittaluga, S., Maeda, L. S., et al.: Dose-adjusted EPOCH-rituximab therapy in primary mediastinal B-cell lymphoma. N. Engl. J. Med., 2013, 368(15), 1408-1416.

[32] Dunleavy, K., Steidl, C.: Emerging biological insights and novel treatment strategies in primary mediastinal large B-cell lymphoma. Semin. Hematol., 2015, 52(2), 119-125.

[33] Omuro, A., Correa, D. D., DeAngelis, L. M., et al.: R-MPV followed by high-dose chemotherapy with TBC and autologous stem-cell transplant for newly diagnosed primary CNS lymphoma. Blood, 2015, 125(9), 1403-1410.

[34] Madle, M., Krämer, I., Lehners, N., et al.: The influence of rituximab, high-dose therapy followed by autologous stem cell transplantation, and age in patients with primary CNS lymphoma. Ann. Hematol., 2015, 94(11), 1853-1857.

[35] Takasaki, H., Yamamoto, W., Ishii, Ү., et al.: Post-treatment PETCT findings may predict the prognosis of DLBCL with a bulky mass. Indian J. Hematol. Blood Transfus., 2015, 31(3), 346351.

[36] Mounier, N., Canals, C., Gisselbrecht, C., et al.: High-dose therapy and autologous stem cell transplantation in first relapse for diffuse large $\mathrm{B}$ cell lymphoma in the rituximab era: an analysis based on data from the European Blood and Marrow Transplantation Registry. Biol. Blood Marrow Transplant., 2012, 18(5), 788-793.

[37] Alcantara, M., Dupuis, J., Mareschal, S., et al.: PET/CT before autologous stem cell transplantation predicts outcome in refractory/relapsed follicular lymphoma. Eur. J. Nucl. Med. Mol. Imaging, 2015, 42(2), 215-221.

[38] Evens, A. M., Rosen, S. T., Helenowski, I., et al.: A phase I/II trial of bortezomib combined concurrently with gemcitabine for relapsed or refractory DLBCL and peripheral T-cell lymphomas. Br. J. Haematol., 2013, 163(1), 55-61.

[39] Offner, F., Samoilova, O., Osmanov, E., et al.: Frontline rituximab, cyclophosphamide, doxorubicin, and prednisone with bortezomib (VR-CAP) or vincristine (R-CHOP) for non-GCB DLBCL. Blood, 2015, 126(16), 1893-1901.

[40] Dunleavy, K., Pittaluga, S., Czuczman, M. S., et al.: Differential efficacy of bortezomib plus chemotherapy within molecular subtypes of diffuse large B-cell lymphoma. Blood, 2009, 113(24), 6069-6076.
[41] Velichutina, I., Shaknovich, R., Geng, H., et al.: EZH2-mediated epigenetic silencing in germinal center B cells contributes to proliferation and lymphomagenesis. Blood, 2010, 116(24), 52475255 .

[42] Nowakowski, G. S., LaPlant, B., Macon, W. R., et al.: Lenalidomide combined with R-CHOP overcomes negative prognostic impact of non-germinal center B-cell phenotype in newly diagnosed diffuse large B-cell lymphoma: a phase II study. J. Clin. Oncol., 2015, 33(3), 251-257.

[43] Martín, A., Redondo, A. M., Dlouby, I., et al.: Lenalidomide in combination with R-ESHAP in patients with relapsed or refractory diffuse large B-cell lymphoma: a phase $1 \mathrm{~b}$ study from GELTAMO group. Br. J. Haematol., 2016, 173(2), 245-252.

[44] Witzig, T. E., Reeder, C. B., LaPlant, B. R., et al.: A phase II trial of the oral mTOR inhibitor everolimus in relapsed aggressive lymphoma. Leukemia, 2011, 25(2), 341-347.

[45] Micallef, I. N., Maurer, M. J., Wiseman, G. A., et al.: Epratuzumab with rituximab, cyclophosphamide, doxorubicin, vincristine, and prednisone chemotherapy in patients with previously untreated diffuse large B-cell lymphoma. Blood, 2011, 118(15), 4053-4061.

[46] Jacobsen, E. D., Sharman, J. P., Oki, Ү., et al.: Brentuximab vedotin demonstrates objective responses in a phase 2 study of relapsed/refractory DLBCL with variable CD30 expression. Blood, 2015, 125(9), 1394-1402.

[47] Viardot, A., Goebeler, M. E., Hess, G., et al.: Phase 2 study of the bispecific T-cell engager (BiTE) antibody blinatumomab in relapsed/refractory diffuse large B-cell lymphoma. Blood, 2016, $127(11), 1410-1416$.

[48] De Vos, S., Forero-Torres, A., Ansell, S. M., et al.: A phase II study of dacetuzumab (SGN-40) in patients with relapsed diffuse large B-cell lymphoma (DLBCL) and correlative analyses of patientspecific factors. J. Hematol. Oncol., 2014, 7, 44.

[49] Palanca-Wessels, M. C., Czuczman, M., Salles, G., et al.: Safety and activity of the anti-CD79B antibody-drug conjugate polatuzumab vedotin in relapsed or refractory B-cell non-Hodgkin lymphoma and chronic lymphocytic leukaemia: a phase 1 study. Lancet Oncol., 2015, 16(6), 704-715.

[50] Preliminary results of a phase II randomized study (ROMULUS) of polatuzumab vedotin or pinatuzumab vedotin plus rituximab in patients with relapsed/refractory non-Hodgkin lymphoma (NHL). Clin. Adv. Hematol. Oncol., 2014, 12(8 Suppl. 16), 15-18.

(Gergely Lajos dr., Debrecen, Nagyerdei krt. 98., 4032 e-mail: lgergely.work@gmail.com) 